Alina HacZeK

Uniwersytet Pedagogiczny, Kraków, Polska

\title{
Transformacja struktur przemysłowych Bielska-Białej
}

\section{Transformation of industrial structures in Bielsko-Biala}

\begin{abstract}
Streszczenie: Zmiana systemu gospodarowania po 1989 roku, związana z odejściem od gospodarki centralnie planowej i wprowadzeniem gospodarki rynkowej, wpłynęła bezpośrednio na przekształcenie struktury gospodarczej Polski. Najbardziej dynamiczne i zauważalne przemiany nastąpiły w sektorze przemysłowym. Zmianom podlega nie tylko struktura przestrzenna i działowa przemysłu, ale także jego rola w kształtowaniu rozwoju gospodarczego różnej skali układów przestrzennych. W świetle powyższych założeń $\mathrm{w}$ pracy podjęto problematykę transformacji struktur przemysłowych Bielska-Białej. Miasto to, historycznie związane z działalnością przemysłową, w ostatnich kilkudziesięciu latach zmieniło swój gospodarczy charakter. Celem pracy jest przedstawienie zmian, jakie dokonały się w bielskim sektorze przemysłowym w latach 1976-2005, ze szczególnym uwzględnieniem wpływu procesów transformacji gospodarczej, a także nasilających się w ostatnich latach procesów integracji europejskiej oraz procesów globalizacji, a zwłaszcza ocena wpływu światowego kryzysu gospodarczego na zahamowanie aktywności bielskiego sektora przemysłowego. Analiza danych statystycznych i literatury wykazała, że stracił na znaczeniu tradycyjny dla Bielska-Białej przemysł włókienniczy, a zaczął dominować przemysł motoryzacyjny. Na napływ nowych inwestorów, w tym inwestorów zagranicznych, a tym samym upowszechnianie się nowych technologii i nowych gałęzi przemysłu, w dużym stopniu oddziałało włączenie czterech obszarów miasta do podstrefy żorsko-jastrzębskiej Katowickiej Specjalnej Strefy Ekonomicznej, a także utworzenie Parku Przemysłowo-Technologicznego. Przedstawione w artykule wnioski są próbą odpowiedzi na pytanie, jaką rolę we współczesnych latach pełni sektor przemysłowy w rozwoju gospodarczym miasta.
\end{abstract}

Abstract: The change of the management system after the year 1989, connected with the conversion
from a centrally planned economy to the introduction of a market economy, directly influenced the
transformation of the Polish economic structures. The most dynamic and noticeable changes occurred
in the industrial sector. Besides changes in spatial structure and the partition of industry, the role of
industry in economic development of different scale spatial systems also changed. The article discusses
the problem of the transformation of industrial structures in Bielsko-Bia la. The city is historically as-
sociated with industrial activities and had changed its economic character over the past few years. The
aim of the paper is to present the changes that took place in the industrial sector of Bielsko-Biała in the
years $1976-2005$, with a particular emphasis on the impact of the economic transformation processes,
as well as the intensification of European integration and globalization processes in recent years. The
article also analyzes the impact of the global economic crisis on the development of Bielsko-Biala's
industrial sector. The results of this study showed that the textile industry, which is the main traditional 
industry for Bielsko-Biała, has become less important, and that now the automotive industry has begun to dominate. The large impact of the influx of new investors, including foreign investors, and thus the dissemination of new technologies and new industries, was the inclusion of (four) parts of the city to the Katowice Special Economic Zone and the creation of the Technology and Industry Park. The conclusions presented in this article are an attempt to answer the question of the role the industrial sector had fulfilled in recent years in the economic development of the city.

Słowa kluczowe: Bielsko-Biała; kryzys; przemysł; Specjalna Strefa Ekonomiczna (SSE)

Keywords: Bielsko-Biała; crisis; industry; Special Economic Zone (SEZ)

\section{WSTĘP}

Zmiana systemu gospodarowania po 1989 roku, związana z odejściem od gospodarki centralnie planowanej i wprowadzeniem gospodarki rynkowej, wpłynęła bezpośrednio na przekształcenie struktury gospodarczej Polski. Najbardziej dynamiczne i zauważalne przemiany nastąpiły w sektorze przemysłowym (Czapliński, 2006; Rachwał, 2010). Zmianom podlega nie tylko struktura przestrzenna i działowa przemysłu, ale także jego rola w kształtowaniu rozwoju gospodarczego różnej skali układów przestrzennych. Transformacja ta związana jest $\mathrm{z}$ dopasowaniem istniejącej infrastruktury oraz zatrudnionych pracowników do zmieniających się warunków gospodarki, zwłaszcza do gospodarki opartej na wiedzy, a także z kształtowaniem społeczeństwa informacyjnego (Bal-Woźniak, 2009). W ostatnich latach na przemiany struktur przemysłowych wpłynął szereg różnorodnych czynników związanych w głównej mierze z postępującymi procesami globalizacji i integracji europejskiej, a także globalnym kryzysem gospodarczym, którego pierwsze efekty można było zaobserwować w 2007 roku (Rachwał, 2011). Światowa sytuacja kryzysowa wpłynęła na zmiany uwarunkowań funkcjonowania i rozwoju przedsiębiorstw przemysłowych oraz zmiany tempa rozwoju struktur różnej skali układów przestrzennych. Kryzys, który rozpoczął się od systemu bankowego, miał także wpływ na ograniczenie inwestycji oraz działalności produkcyjno-usługowej, a co się z tym wiąże - spowodował także spadek zatrudnienia i wzrost bezrobocia (Zioło, 2011).

W świetle powyższych założeń podjęto problematykę transformacji struktur przemysłowych w odniesieniu do Bielska-Białej, które, historycznie związane z działalnością przemysłową, przeszło w ostatnich kilkudziesięciu latach wiele przeobrażeń charakteru gospodarczego. Celem pracy jest przedstawienie zmian, jakie dokonały się w bielskim sektorze przemysłowym, ze szczególnym uwzględnieniem wpływu procesów transformacji gospodarczej, nasilających się procesów globalizacji i integracji europejskiej, a zwłaszcza ocena wpływu kryzysu światowego na zahamowanie aktywności bielskiego sektora przemysłowego.

We wstępie przedstawiono historyczne uwarunkowania rozwoju przemysłu na terenie Bielska-Białej, następnie na podstawie danych uzyskanych z Banku Danych Lokalnych GUS przedstawiono zmianę liczby i struktury pracujących w latach 1976-2011. Dokonano także analizy zmian liczby podmiotów gospodarczych w latach 1995-2011, a także szczegółowo przedstawiono strukturę bielskiego przemysłu w 2012 roku. Na zakończenie omówiono najnowsze 
przedsięwzięcia, jakie zrealizowano w ostatnich latach, aby zwiększyć atrakcyjność inwestycyjną miasta, a mianowicie utworzenie Beskidzkiego Parku Przemysłowo-Technologicznego oraz włączenie części miasta w skład Katowickiej Specjalnej Strefy Ekonomicznej (KSSE).

\section{Z PRZESZŁOŚCI BIELSKIEGO PRZEMYSŁU}

Bielsko-Biała jest miastem na prawach powiatu, głównym ośrodkiem aglomeracji bielskiej, centrum bielskiego ośrodka przemysłowego (Gierańczyk, Stańczyk, 2001). Miasto wyrosło z dwóch konkurujących ze sobą ośrodków rękodzielnictwa sukienniczego - Bielska i Białej (Batorowicz, Suliborski, 1988). Już w 1548 r. w Bielsku powstał cech sukienników, który przyciągnął wielu specjalistów z całej Polski, Dolnego Śląska i Niemiec. Do głównych czynników rozwoju sukiennictwa na tym terenie należały: dogodny dostęp do surowca wełny, czysta woda górska z bielskich potoków, położenie na szlaku handlowym, a także przychylność władców i liczne nadawane przez nich przywileje, jak chociażby przywilej na farbowanie sukna z 1626 r. W XVII i XVIII w. Bielsko było najsilniejszym ośrodkiem rzemieślniczym i handlowym Śląska Cieszyńskiego, eksportującym swoje wyroby m.in. na Węgry, do Turcji i na Bałkany. Od początku XIX w., w związku z wojną i nałożonym przez Napoleona embargiem na importowanie wyrobów z Wielkiej Brytanii, od początku XIX w. nastąpił ogromny wzrost zapotrzebowania na bielskie włókna, przyczyniający się tym samym do rozkwitu bielskiego przemysłu włókienniczego. Zastosowano wtedy pierwsze mechaniczne przędzalnie, a w 1826 r. po raz pierwszy uruchomiono w Bielsku maszynę parową. Dynamiczny rozwój włókiennictwa pociągnął za sobą rozbudowę przede wszystkim przemysłu metalowego oraz maszynowego, a także, na mniejszą skalę, przemysłu materiałów budowlanych, przemysłu drzewnego i spożywczego. Następnym ważnym wydarzeniem w życiu miasta było uzyskanie połączenia kolejowego z Wiedniem, a także organizacja, wspólnie z sąsiedzką Białą, wielkiej wystawy przemysłowej w $1871 \mathrm{r}$. Przez wiele lat miasto dynamizowało procesy produkcji zakładów przemysłowych, dobrą koniunkturę gospodarczą pogorszył dopiero kryzys gospodarczy w latach 1930-1934. W okresie II wojny światowej Bielsko pozostało prężnym ośrodkiem gospodarczym, produkującym na potrzeby III Rzeszy (Polak, 2000)

Sąsiednie młodsze miasto Biała również ma tradycje włókiennicze - w 1667 roku założono tutaj cech tkaczy. Jeszcze przed pierwszym zaborem miasto zyskało rangę jednego z najważniejszych ośrodków sukienniczych w zachodniej Małopolsce. Podobnie jak w Bielsku, początek XIX w. przyniósł przekształcenie drobnych zakładów tkackich w fabryki włókiennicze. Pierwszy duży zakład powstał w 1810 r., a miasto, dbając o swoją renomę, organizowało słynne bielskie jarmarki wełny. Chociaż Biała rozwijała się równolegle do Bielska, nigdy nie osiągnęła jego potencjału produkcyjnego. Z powodu licznych strajków robotników na tle narodowościowym, ekonomicznym i politycznym od 1916 r. nastąpiło zahamowanie produkcji i postępu przemysłowego miasta, powodując znaczne zacofanie w stosunku do nowoczesnego i prężnie prosperującego sąsiada (Polak, 2010). 
Po połączeniu w 1951 r. Bielska i Białej w jeden organizm miejski nastąpił gwałtowny rozwój procesów industrializacji, powstało wiele nowych zakładów przemysłowych (m.in. Zakład Wyrobów Śrubowych „Bispol”, Zakłady Przemysłu Odzieżowego „Bielkon”, Zakład Wyposażenia Budowlanego „Metalplast”), dokonano także rozbudowy i modernizacji zakładów już istniejących. Ponadto w celu powiązania produkcji w obrębie przemysłu włókienniczego i elektromaszynowego scalono wiele działających już wcześniej fabryk. W licznych zakładach włókienniczych przeprowadzono wymianę maszyn na bardziej nowoczesne, a także zwiększano asortyment produkowanych tkanin. Aby zniwelować wysokie ceny importu wełny, na coraz szerszą skalę zaczęto wprowadzać tkaniny z włókien syntetycznych. Już w połowie lat 60 . XX w. bielski przemysł wełniany, który wytwarzał ponad 16,6 mln metrów bieżących tkanin, w produkcji tkanin z włókien syntetycznych wysunął się na czołowe miejsce w kraju (Kaczmarek, 2010: 515).Większość zakładów znaczną część swoich wyrobów przeznaczała na eksport, m.in. do Stanów Zjednoczonych Ameryki Północnej, Kanady, Japonii, Belgii, RFN, Hongkongu, Indonezji czy krajów Bliskiego Wschodu. W latach 70. XX w. wiele bielskich zakładów przeżywało rozkwit, mogło poszczycić się dynamicznym wzrostem produkcji, część z nich zdecydowało się także na przeniesienie poza centrum miasta. Do najprężniej działających w tym okresie zakładów włókienniczych zaliczyć można: „Welux” (ZPW im. S. Niedzielskiego), „Krepol” (ZPW im. S. Bularza), „Finex” (ZPW im. P. Findera), Zakłady Przemysłowo-Włókiennicze „Lenko” S.A., a do zakładów odzieżowych: Zakłady Przemysłu Odzieżowego „Bielkon”, Bielskie Zakłady Obuwia „Befado”. Przemysł włókienniczy wspomagały także liczne zakłady przemysłu elektromaszynowego, np. Bielska Fabryka Maszyn „Befama”, Fabryka Aparatów Elektrycznych „Apena”, Zakłady Wytwórcze Sprzętu Sieciowego „Belos”. Na mapie przemysłowej Bielska wyróżniały się także zakłady reprezentujące inne branże, jak chociażby Bielskie Zakłady Podzespołów Lampowych „Polam-Bielsko”, Bielskie Zakłady Przemysłu Tłuszczowego, Fabryka Pił i Narzędzi „Wapienica” czy Zakłady Szybowcowe Delta-Bielsko (Kaczmarek, 2010).

Przełomowym momentem dla bielskiego przemysłu, który wywarł ogromny wpływ na dalsze losy gospodarcze miasta, był rok 1971, kiedy rozpoczęto budowę Fabryki Samochodów Małolitrażowych (FSM). Powstała ona na fundamencie Wytwórni Sprzętu Mechanicznego, która funkcjonowała w Bielsku już od 1872 r., a w 1965 r. połączono ją z Zakładami Sprzętu Motoryzacyjnego. W skład FSM włączono także wiele innych zakładów, m.in. Bielską Fabrykę Obrabiarek, Starobielską Fabrykę Kos w Wapienicy i Zakłady Metalowe im. Juliana Marchlewskiego. Początkowo zakłady produkowały samochody marki Syrena, a od czerwca 1973 r. ruszyła produkcja Fiata 126 p (Kaczmarek, 2010). Od tego momentu miasto zaczęło zmieniać swój gospodarczy charakter z ośrodka nieco zacofanego już przemysłu lekkiego w ośrodek oparty na nowoczesnej branży motoryzacyjnej. Rozwój przemysłu samochodowego uważać należy tutaj za szczególnie ważny nośnik postępu technicznego i unowocześnienia całego przemysłu. Wraz z rozwojem potencjału produkcyjnego i dynamiką produkcji ulegały zmianie różnorodne układy struktur, przede wszystkim przestrzenna, gałęziowa i ekonomiczna oraz ich znaczenie. Ewolucje zmian strukturalnych przemysłu zachodziły stopniowo wraz ze wzrostem nakładów inwestycyjnych oraz koncentracją majątku trwałego (Pakuła, 1986: 14). 
Lata 80 . były jednym $\mathrm{z}$ najtrudniejszych okresów w historii bielskiego przemysłu. Ogólnokrajowy kryzys gospodarczy, a także znaczny wzrost cen importowanych surowców spowodowały, że produkcja przestała być opłacalna, dlatego też wiele zakładów zaczęło borykać się z problemami finansowymi i wprowadziło redukcję zatrudnienia.

\section{BIELSKI PRZEMYSE W OKRESIE TRANSFORMACJI GOSPODARCZEJ}

Po 1989 roku zasadniczo zmieniła się struktura bielskiego przemysłu. Najwidoczniejsze zmiany zaszły w branży przemysłu włókienniczego, w przeciągu tylko trzech lat (19901993) produkcja w tych zakładach spadła o 55\%, a zatrudnienie zmniejszono o 4 tys. pracowników. Głównych przyczyn takiej sytuacji można upatrywać w spadku eksportu na rynki wschodnie, dużo niższych cenach oferowanych przez producentów z Chin, Korei, Turcji, Czech i Słowacji, a także problemy z dostosowaniem się przedsiębiorstw do nowych warunków wynikających z transformacji ustrojowo-gospodarczej. Wiele bielskich zakładów włókienniczych zlikwidowano w latach 90. XX w. i na początku XXI w. Przykładem jest Zakład Przemysłu Włókienniczego „Bewelana”, który ogłosił upadłość w 1993 r., a jeszcze w latach 80. XX w. zatrudniał około 2 tys. pracowników. Podobne losy spotkały ZPW „Bielska Dzianina” (upadłość w 1994 r.) oraz ZPW „Merilana” (2002 r.). Ponadto, pomimo prywatyzacji, wiele zakładów nie poradziło sobie z nowymi wymogami rynku i zbankrutowało. Przykładowo ZPW „Wega”, sprywatyzowane w 1995 roku, ogłosiły upadłość 5 lat później. ZPW „Krepol”, po sprywatyzowaniu w 1997 i połączeniu z ZPW „Welux” w 1998 r., już w 2001 roku był w stanie likwidacji. Pomimo prób ratowania bielskich zakładów włókienniczych poprzez program „Bielska Wełna Bis”, większość z nich została zamknięta, a tradycje włókienniczo-odzieżowe Bielska-Białej kontynuują dziś tylko nieliczne zakłady, m.in. „Lenko” S.A., działające od 1890 roku, oraz „Krepol” Sp. z o.o., reaktywowany w 2007 roku przez nowych inwestorów (Lenko - historia, 2013; Krepol-o firmie, 2013)

Spośród znaczących zakładów działających w innych branżach przemysłu należy wspomnieć o Zakładach Szybowcowych PZL, które ogłosiły upadłość w 1999 roku. Wiele pozostałych zakładów było zmuszonych znacznie ograniczyć produkcję oraz liczbę zatrudnionych pracowników, tak jak Fabryka Maszyn Włókienniczych „Bafama”, która w okresie najlepszej koniunktury na swoje produkty w latach 70. XX w. zatrudniała ponad 4,2 tys. ludzi, natomiast w ostatnich latach zatrudnienie to kształtowało się mniej więcej na poziomie niewiele ponad 100 pracowników (Kaczmarek, 2010).

Przykładem udanej prywatyzacji było przejęcie Bielskich Zakładów Lampowych „Polam-Bielsko” przez koncern „Philips” i utworzenie firmy „Philips Lighting Bielsko” Sp. z o.o. Procesy prywatyzacji przyniosły pozytywne efekty również w Fabryce Samochodów Małolitrażowych. Po prywatyzacji w 1992 roku nowa spółka „Fiat Auto Poland” S.A. zaczęła się prężnie rozwijać, zwiększono produkcję, a kapitał zainwestowany w modernizację zakładu pozwolił zwiększyć zatrudnienie o 7,5 tys. pracowników. W 2003 roku we współpracy „Fiata” z koncernem „General Motors” powstała spółka „Fiat Powertrain Polska”, która 
produkuje silniki nowej generacji (Kaczmarek, 2010). Już w 2004 roku przedsiębiorstwo znalazło się w czołówce polskich firm przemysłowych z kapitałem zagranicznym, osiągając przychody ze sprzedaży w wysokości 10,1 mld zł i zatrudniało ponad 16 tys. pracowników (Śleszyński, 2007).

Tab. 1. Zmiany liczby i struktury pracujących w latach 1976-1995

\begin{tabular}{|c|c|c|c|c|c|c|c|}
\hline \multirow{2}{*}{ Lata } & \multicolumn{3}{|c|}{ Liczba pracujących } & \multicolumn{3}{c|}{ Struktura pracujących } \\
\cline { 2 - 8 } & ogółem & $\begin{array}{c}\text { rolnictwo, } \\
\text { lowiectwo, } \\
\text { leśnictwo } \\
\text { i rybactwo }\end{array}$ & $\begin{array}{c}\text { przemysł } \\
\text { i budownictwo }\end{array}$ & usługi & $\begin{array}{c}\text { rolnictwo, } \\
\text { fowiectwo, } \\
\text { leśnictwo } \\
\text { i rybactwo }\end{array}$ & przemysł & i budownictwo \\
\hline 1976 & 110659 & 1196 & 79238 & 30225 & 1,08 & 71,61 & 27,31 \\
\hline 1985 & 93102 & 916 & 56977 & 35209 & 0,98 & 61,2 & 37,82 \\
\hline 1995 & 72832 & 254 & 38463 & 34115 & 0,35 & 52,81 & 46,84 \\
\hline
\end{tabular}

Źródło: opracowanie własne na podstawie danych GUS oraz Rozwój przemyslu i przemiany struktury przestrzenno-gałęziowej województwa... (1986).

Jednym z przejawów dokonujących się przemian gospodarczo-systemowych była zmiana liczby i struktury sektorowej pracujących w Bielsku-Białej. W latach 1976-1985 nastąpił ich spadek z 110659 do 93 102, czyli o 15,9\% (tab. 1). Jego główną przyczyną był ogólny kryzys gospodarczy w kraju oraz wynikający z niego spadek produkcji. W następnym dziesięcioleciu zaobserwować można również tendencję spadkową w liczebności pracujących osób. Zanotowano spadek z 93102 osób w 1985 r. do 72832 w 1995 r., czyli o $21,8 \%$, spowodowany w głównej mierze problemami dostosowania się przedsiębiorstw do nowych warunków gospodarki rynkowej. W zasadniczy sposób zmianie uległa także sektorowa struktura pracujących. W badanym okresie nastąpił spadek udziału osób pracujących w I sektorze gospodarki (rolnictwo, łowiectwo, leśnictwo i rybactwo) w stosunku do ogółu pracowników - z 1,1\% w 1976 r. do 0,4\% w 1995 r., a także w II sektorze (przemysł i budownictwo) z 71,6\% do 52,8\%. Jednocześnie w tym samym przedziale czasu nastąpił wzrost udziału pracujących w III sektorze gospodarki (usługi) z 27,3\% do 46,8\%.

Po 1995 roku, pod wpływem coraz bardziej nasilających się procesów transformacji systemowej, w dalszym ciągu widocznie były wahania liczby pracujących w Bielsku-Białej, lecz dynamika tych zmian była zdecydowanie niższa niż we wcześniejszym dwudziestoleciu. W pierwszym okresie nastąpił dalszy spadek liczby pracujących z $72832 \mathrm{w} 1995 \mathrm{r}$. do 56231 w 2002 r., czyli o 22,8\% (ryc.1). W następnym okresie liczba ta zaczęła powoli rosnąć, w 2008 r. wynosiła 68 491, czyli nastąpił wzrost o 21,8\%. W 2009 roku zanotowano spadek do poziomu 66 991, czyli o 2,2\%. Zmniejszenie się liczby pracujących w tym momencie niewątpliwie było efektem światowego kryzysu gospodarczego. W następnych dwóch latach nastąpił ponowny wzrost do 69590 osób, czyli o 3,9\%.

Ponadto przemianom uległa także struktura pracujących. Analiza zmian ich udziału w II sektorze gospodarki, czyli w przemyśle i budownictwie, w ich ogólnej liczbie wykazuje zmniejszanie się roli tego sektora w aktywizacji zasobów pracy. W latach 1995-2011 udział 
sektora przemysłu i budownictwa zmniejszył się z 52,8 do 43,4\%, przy czym można wyróżnić tutaj fazy tych przemian: w latach 1995-2002 spadek udziału przemysłu w zatrudnieniu z 52,8 do 40,6\%, w latach 2003-2011 niewielki wzrost do 43,4\%. Warto odnotować tutaj wyraźny spadek pracujących w przemyśle oraz ich udziału w ogóle osób pracujących w roku 2009, związany z reakcjami rynku pracy na kryzys gospodarczy. Mimo że udział pracujących w sektorze przemysłu i budownictwa zmniejszył się w badanym okresie, kształtował się on na dość wysokim poziomie (nie spadł poniżej 40\%). Warto tutaj dodać, iż w $2011 \mathrm{r}$. średni udział pracujących w Polsce w przemyśle i budownictwie wynosił 28,0\%. Odmiennie sytuacja kształtowała się w III sektorze gospodarki, czyli w usługach. W latach 1995-2011 udział tego sektora w ogóle osób pracujących zwiększył się z 46,8 do 55,6\%, przy czym w pierwszym okresie (1995-2002) nastąpił gwałtowny wzrost udziału usług w zatrudnieniu do 58,9\%, a w latach 2003-2011 spadek do 55,6\%. Należy podkreślić, że chociaż sektor usług ma od 1998 roku dominujące znaczenie w aktywizacji zasobów pracy, to jego znaczenie w ostatnich latach maleje, na co niewątpliwie wpływ mają podejmowane w BielskuBiałej inwestycje w celu ożywienia sektora przemysłowego.

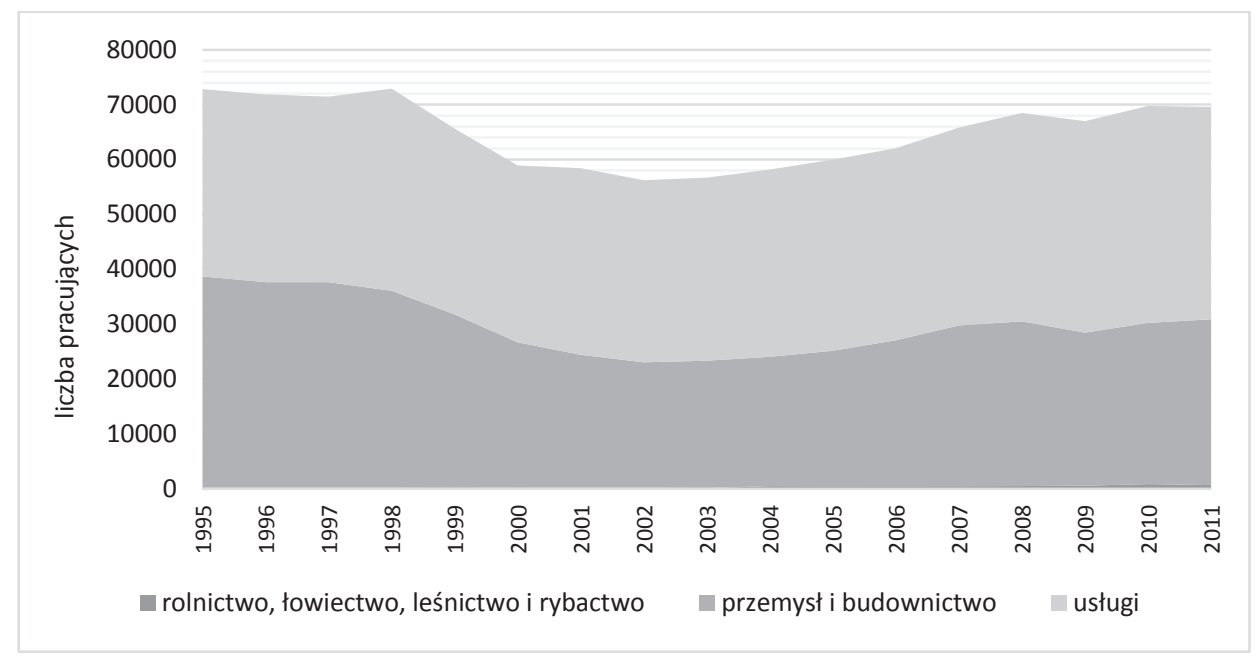

Ryc. 1. Zmiany struktury pracujących w Bielsku-Białej wg sektorów gospodarki w latach 1995-2011

Źródło: opracowanie własne na podstawie danych GUS

W konsekwencji procesów transformacji systemowej, a także większej swobody w zakresie prowadzenia prywatnej działalności gospodarczej, zaszły także znaczne zmiany w zakresie liczby działających w Bielsku-Białej podmiotów gospodarczych. W analizowanym okresie ich liczba wzrosła z 16985 w 1995 r. do 25163 w 2012 r., czyli o 48,2\% (ryc. 2). Można tutaj wyróżnić okresy: 1995-2002 - okres gwałtownego wzrostu, 2002-2007 - spadek aktywności oraz ponowny wzrost w latach 2008-2010. W roku 2011 nastąpił niewielki spadek, natomiast w 2012 roku liczba zarejestrowanych podmiotów gospodarczych była najwyższa od 1995 roku. Świadczyć to może o dobrej koniunkturze gospodarczej miasta 
i wzroście aktywności po krótkotrwałym okresie kryzysu. W badanym okresie w strukturze własnościowej podmiotów gospodarczych dominujące znaczenie miał sektor prywatny, z niewielkimi wahaniami należało do niego powyżej 96\% przedsiębiorstw.

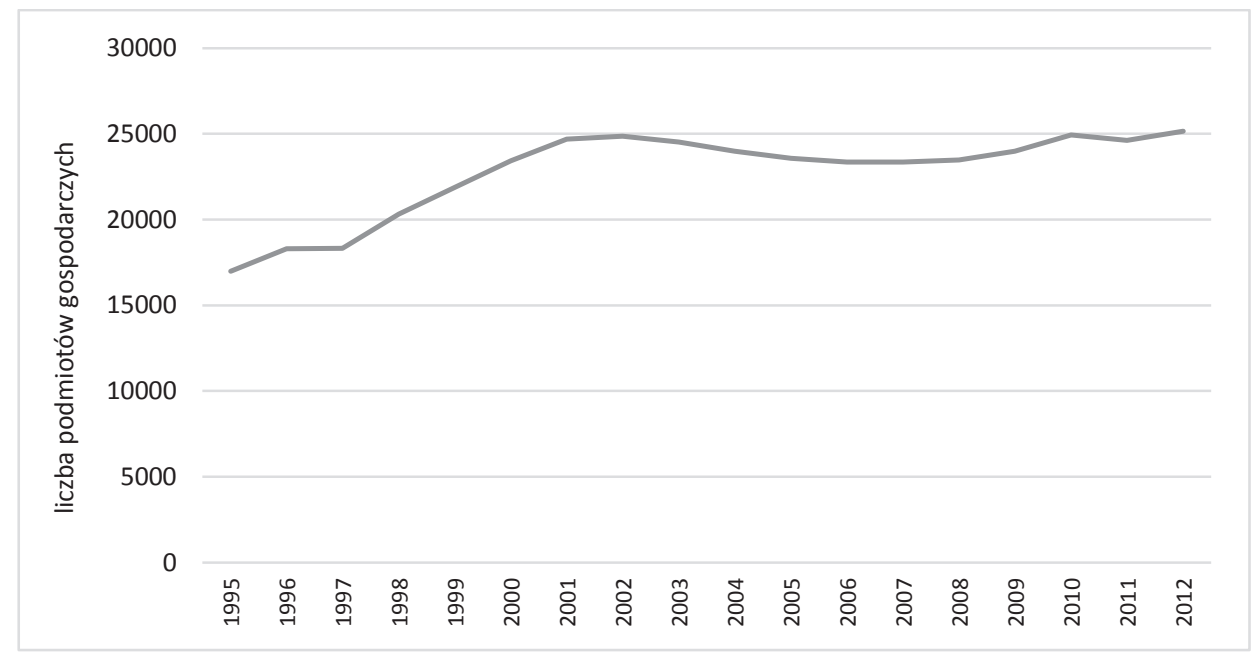

Ryc. 2. Zmiany liczby podmiotów gospodarczych w Bielsku-Białej w latach 1995-2012

Źródło: opracowanie własne na podstawie danych GUS

\section{Podmioty gospodarcze dzialające w Bielsku-Bialej}

Analizując dane dotyczące struktury podmiotów gospodarczych działających w BielskuBiałej, należy zauważyć, że największe znaczenie w tym zakresie w 2012 roku miał sektor III, czyli usług, który skupiał 19753 podmiotów, czyli 78,6\% (ryc. 3). Do sektora II, obejmującego przemysł i budownictwo, należało 5268 podmiotów, czyli 21,0\%. Natomiast najmniejszą grupę stanowił sektor I - rolnictwa, łowiectwa, leśnictwa i rybactwa, skupiający jedynie 112 podmiotów, co daje udział $0,4 \%$ w ich ogólnej liczbie.

Na podstawie szczegółowej analizy podmiotów gospodarczych w podziale na sekcje PKD 2007 można zauważyć, że dominujące znaczenie pod tym względem w 2012 roku miała sekcja G, obejmująca handel hurtowy i detaliczny, naprawę pojazdów samochodowych (włączając motocykle), do której zaklasyfikowano 6952 podmiotów, czyli 28,0\%. Udział powyżej 10\% w ogólnej liczbie podmiotów gospodarczych mają także sekcje: F - budownictwo (10,6\%), $\mathrm{M}$ - działalność profesjonalna, naukowa i techniczna $(10,3 \%)$ oraz $\mathrm{C}$ - przetwórstwo przemysłowe $(10,0 \%)$.

Wśród podmiotów gospodarczych zaliczanych do działalności przemysłowej największe znaczenie ma wspomniana już wcześniej sekcja C, do której należało aż 96,5\% wszystkich podmiotów branży sektora przemysłowego (tab. 2). Dużo mniejsze znaczenie miały 
sektory E (dostawa wody; gospodarowanie ściekami i odpadami oraz działalność związana z rekultywacją), D (wytwarzanie i zaopatrywanie w energię elektryczną, gaz, parę wodną, gorącą wodę i powietrze do układów klimatyzacyjnych) i B (górnictwo i wydobywanie), do których zaklasyfikowano odpowiednio $2,3 \%, 0,9 \%, 0,3 \%$ podmiotów.

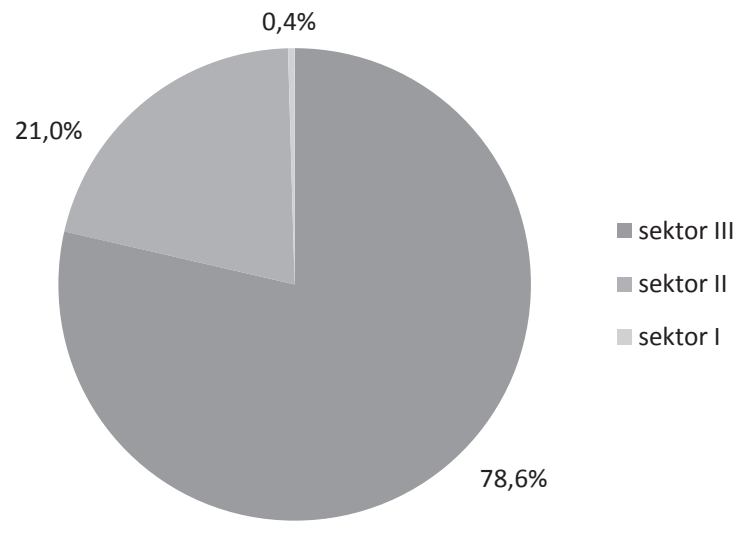

Ryc. 3. Struktura podmiotów gospodarczych według sektorów gospodarki zarejestrowanych w Bielsku-Białej w 2012 roku

Źródło: opracowanie własne na podstawie danych GUS

Tab. 2. Struktura podmiotów gospodarczych prowadzących działalność przemysłową w Bielsku-Białej według sekcji PKD 2007 w 2012 roku

\begin{tabular}{|l|c|}
\hline \multicolumn{1}{|c|}{ Sekcje } & $\begin{array}{c}\text { Liczba podmiotów } \\
\text { gospodarczych }\end{array}$ \\
\hline sekcja C & 2528 \\
\hline sekcja E & 61 \\
\hline sekcja D & 23 \\
\hline sekcja B & 8 \\
\hline
\end{tabular}

Źródło: opracowanie własne na podstawie danych GUS

W 2012 roku w ramach sekcji C (przetwórstwo przemysłowe) działało 2528 podmiotów gospodarczych, czego największą część stanowiły przedsiębiorstwa produkujące wyroby metalowe - było ich 389, co stanowiło $15,4 \%$ wszystkich podmiotów (tab. 3). Natomiast przedsiębiorstw, które zajmują się tradycyjną dla Bielska-Białej działalnością produkcyjną (produkcja odzieży - dział 14, produkcja wyrobów odzieżowych - dział 13, produkcja maszyn i urządzeń - dział 28) było 492, czyli 19,5\%. 
Tab. 3. Podmioty gospodarcze zarejestrowane w Bielsku-Białej według działów sekcji C w 2012 roku

\begin{tabular}{|c|c|}
\hline dział & liczba podmiotów gospodarczych \\
\hline 25 & 389 \\
\hline 14 & 313 \\
\hline 33 & 280 \\
\hline 32 & 199 \\
\hline 22 & 196 \\
\hline 10 & 164 \\
\hline 18 & 162 \\
\hline 31 & 120 \\
\hline 16 & 109 \\
\hline 23 & 109 \\
\hline 13 & 95 \\
\hline 28 & 84 \\
\hline 27 & 56 \\
\hline 29 & 56 \\
\hline 26 & 45 \\
\hline 17 & 43 \\
\hline 15 & 26 \\
\hline 20 & 25 \\
\hline 30 & 24 \\
\hline 24 & 20 \\
\hline 11 & 12 \\
\hline 19 & 1 \\
\hline & \\
\hline
\end{tabular}

Legenda: 25 - produkcja metalowych wyrobów z wyłączeniem maszyn, 14 - produkcja odzieży, 33 - naprawa, konserwacja, instalowanie maszyn, 32 - pozostała produkcja, 22 - produkcja wyrobów z pozostałych mineralnych surowców, 10 - produkcja artykułów spożywczych, 18 - poligrafia i reprodukcja zapisanych nośników informacji, 31 - produkcja mebli, 16 - produkcja wyrobów z korka, 23 - produkcja metalowych wyrobów gotowych (z wyłączeniem maszyn i urządzeń), 13 - produkcja wyrobów tekstylnych, 28 - produkcja maszyn i urządzeń, gdzie indziej niesklasyfikowana, 27 - produkcja urządzeń elektrycznych, 29 - produkcja pojazdów samochodowych, 26 - produkcja komputerów, wyrobów elektronicznych i optycznych, 17 - produkcja papieru i wyrobów z papieru, 15 - produkcja skór i wyrobów ze skór wyprawionych, 20 - produkcja chemikaliów i wyrobów chemicznych, 30 produkcja pozostałego sprzętu transportowego, 24 - produkcja metali, 11 - produkcja napojów, 19 - wytwarzanie i przetwarzanie koksu i produktów rafinacji ropy naftowej

Źródło: opracowanie własne na podstawie danych GUS

Efektem zmian systemowych oraz skutków kryzysu (spadek produkcji i zatrudnienia w sektorze przemysłowym) była potrzeba wprowadzenia działań mających na celu napływ do Bielska-Białej nowych inwestycji oraz utworzenie nowych miejsc pracy. W 1999 roku w skład KSSE, a dokładnie podstrefy żorsko-jastrzębskiej, włączono pierwsze tereny Bielska-Białej. Obecnie strefa obejmuje cztery obszary miasta o łącznej powierzchni 54,8 ha, a w jej obrębie działa 12 inwestorów, 1 inwestycja jest w budowie, a 5 nowych inwestycji jest planowanych (tab. 4). Spośród działających na terenie Bielska w ramach KSSE przedsiębiorstw tylko 2 są przedsiębiorstwami polskimi, natomiast pozostałe powstały dzięki 
kapitałowi zagranicznemu. Najwięcej, bo 6 inwestorów pozyskano we Włoszech, pozostałe pojedyncze przedsiębiorstwa pochodzą z USA, Francji, Niemiec i Japonii. Najwięcej (600) pracowników zatrudnia firma Eaton Automotive Systems Sp. z o.o., która zajmuje się produkcją nowoczesnych części do pojazdów samochodowych. Podobnie firma Magneti Marelli Suspension Systems Bielsko Sp. z o.o., zatrudniająca około 507 pracowników, wytwarza części i akcesoria dla branży motoryzacyjnej. Natomiast firma AVIO Polska Sp. z o.o., która stworzyła miejsca pracy dla około 440 osób, zajmuje się produkcją części do silników lotniczych i napędów morskich.

Tab. 4. Inwestorzy KSSE w Bielsku-Białej

\begin{tabular}{|c|c|c|c|c|c|}
\hline Lp. & Nazwa & Branża & Stan inwestycji & $\begin{array}{c}\text { Kraj } \\
\text { pochodzenia }\end{array}$ & $\begin{array}{c}\text { Szacunkowa } \\
\text { liczba } \\
\text { pracowników }\end{array}$ \\
\hline 1. & $\begin{array}{l}\text { AVIO Polska Sp. } \\
\text { z o.o. }\end{array}$ & lotnicza & $\begin{array}{l}\text { po rozpoczęciu } \\
\text { działalności }\end{array}$ & Włochy & 440 \\
\hline 2. & $\begin{array}{l}\text { Bobrek Aluminium } \\
\text { Sp. z o.o. }\end{array}$ & metalowa & projektowanie & Polska & - \\
\hline 3. & $\begin{array}{l}\text { Cooper Standard } \\
\text { Automotive Polska Sp. } \\
\text { z o.o. }\end{array}$ & motoryzacyjna & w budowie & USA & 420 \\
\hline 4. & $\begin{array}{l}\text { Cornaglia Poland Sp. } \\
\text { z o.o. }\end{array}$ & motoryzacyjna & $\begin{array}{l}\text { po rozpoczęciu } \\
\text { działalności }\end{array}$ & Włochy & 60 \\
\hline 5. & $\begin{array}{l}\text { Eaton Automotive } \\
\text { Systems Sp. z o.o. }\end{array}$ & motoryzacyjna & $\begin{array}{l}\text { po rozpoczęciu } \\
\text { działalności }\end{array}$ & USA & 600 \\
\hline 6. & $\begin{array}{l}\text { Electropoli- } \\
\text { Galwanotechnika Sp. } \\
\text { z o.o. }\end{array}$ & motoryzacyjna & $\begin{array}{l}\text { po rozpoczęciu } \\
\text { działalności }\end{array}$ & Francja & 260 \\
\hline 7. & $\begin{array}{l}\text { Fiat Powertrain } \\
\text { Technologies Poland } \\
\text { Sp. z o.o. } \\
\text { Motoryzacyjna }\end{array}$ & motoryzacyjna & $\begin{array}{l}\text { po rozpoczęciu } \\
\text { działalności }\end{array}$ & Włochy & 270 \\
\hline 8. & $\begin{array}{l}\text { Fiat Services Polska } \\
\text { Sp. z o.o. }\end{array}$ & motoryzacyjna & $\begin{array}{l}\text { po rozpoczęciu } \\
\text { działalności }\end{array}$ & Włochy & 290 \\
\hline 9. & $\begin{array}{l}\text { Henkel Polska Sp. } \\
\text { z o.o. }\end{array}$ & chemiczna & $\begin{array}{l}\text { po rozpoczęciu } \\
\text { działalności }\end{array}$ & Niemcy & 8 \\
\hline 10. & $\begin{array}{l}\text { Ingest Facility Polska } \\
\text { Sp. z o.o. }\end{array}$ & developer & $\begin{array}{l}\text { bez zezwolenia } \\
\text { - działający } \\
\end{array}$ & Włochy & - \\
\hline 11. & $\begin{array}{l}\text { Magneti Marelli } \\
\text { Suspension Systems } \\
\text { Bielsko Sp. z o.o. }\end{array}$ & motoryzacyjna & $\begin{array}{l}\text { po rozpoczęciu } \\
\text { działalności }\end{array}$ & Włochy & 507 \\
\hline 12. & Makita Sp. z o.o. & logistyka & $\begin{array}{l}\text { po rozpoczęciu } \\
\text { działalności }\end{array}$ & Japonia & 35 \\
\hline 13. & MDM NT Sp. z o.o. & budowlana & projektowanie & Polska & 15 \\
\hline 14. & $\begin{array}{l}\text { Multiform Dariusz } \\
\text { Krywult }\end{array}$ & developer & $\begin{array}{l}\text { bez zezwolenia } \\
\text { - działający }\end{array}$ & Polska & 74 \\
\hline
\end{tabular}




\begin{tabular}{|c|l|l|l|l|c|}
\hline 15. & $\begin{array}{l}\text { Pojazdy } \\
\text { Specjalistyczne } \\
\text { Zbigniew Szczęśniak } \\
\text { Sp. z o.o. }\end{array}$ & motoryzacyjna & projektowanie & Polska & 8 \\
\hline 16. & Polmotors Sp. z o.o. & metalowa & projektowanie & Polska & 21 \\
\hline 17. & Takoni Sp. z o.o. & $\begin{array}{l}\text { tworzywa } \\
\text { sztuczne }\end{array}$ & $\begin{array}{l}\text { po rozpoczęciu } \\
\text { działalności }\end{array}$ & Polska & 160 \\
\hline 18. & TI Poland Sp. z o.o. & motoryzacyjna & projektowanie & $\begin{array}{l}\text { Wielka } \\
\text { Brytania }\end{array}$ & - \\
\hline
\end{tabular}

Źródło: opracowanie własne na podstawie Inwestorzy KSSE (2013); Katowicka Specjalna Strefa Ekonomiczna, Park Przemysłowo-Technologiczny (2013)

W 2011 roku w Bielsku-Białej działały 234 podmioty gospodarcze z kapitałem zagranicznym o łącznej wartości 1932,5 mln złotych, co może świadczyć, że miasto posiada wysoki potencjał inwestycyjny.

W celu podniesienia atrakcyjności inwestycyjnej miasta, a tym samym zwiększenia rozwoju gospodarczego oraz stworzenia wielu nowych miejsc pracy, w Bielsku-Białej utworzono Park Przemysłowo-Technologiczny, początkowo działający pod nazwą Park Przemysłowy i Usługowy. Przedsięwzięcie zrealizowano ze środków funduszu Phare 2000 (56\% funduszy), a także środków Budżetu Miasta (25\%) oraz Budżetu Państwa (19\%). Proces budowy parku rozpoczął się w 1999 roku i początkowo polegał na technicznym przygotowaniu wyznaczonych terenów, a następnie na wyszukaniu odpowiednich przedsiębiorstw i zagospodarowaniu przez nich powierzchni inwestycyjnej. Jednym z najważniejszych inwestorów działających na terenie Parku jest Hutchinson Poland Sp. z o.o., firma zajmująca się produkcją części dla przemysłu motoryzacyjnego, zatrudniająca około 326 pracowników. Całościowy koszt jej obecnych i przyszłych inwestycji wyceniono na 15 mld euro. Kolejnym inwestorem działającym na terenie Parku jest firma Multiform Dariusz Krywult, specjalizująca się w branży budowlanej i motoryzacyjnej. Duży wkład w funkcjonowanie Parku ma także Agencja Rozwoju Regionalnego S.A., która do 2011 roku pełniła funkcję jego organu zarządzającego, a także była pomysłodawcą utworzenia Beskidzkiego Inkubatora Przedsiębiorczości (BIP). Celem Inkubatora jest wspieranie rozwoju małych i średnich przedsiębiorstw, bazujących na nowoczesnych i innowacyjnych rozwiązaniach, a także współpraca firm z licznymi ośrodkami naukowymi i badawczo-rozwojowymi. W ramach tego przedsięwzięcia dla nowych inwestorów udostępniono dwa budynki, a także stworzono Centrum Szkoleniowo-Konferencyjne. W ramach BIP swoją działalność prowadzą m.in. firmy informatyczne, projektowe, zajmujące się doradztwem usługowo-finansowym, a także działalnością typowo produkcyjną (Katowicka Specjalna Strefa Ekonomiczna, 2013; Park Przemysłowo-Technologiczny, 2013).

Nakłady inwestycyjne w Bielsku-Białej w latach 2002-2011 charakteryzowały się zmienną dynamiką, ich wartość zmniejszyła się z 1279,1 mln zł w 2002 r. do 960 mln zł w 2011 r., czyli o 25,0\%. Można tutaj wyróżnić dwa okresy spadku - lata 2002-2005, kiedy wartość funduszy przeznaczonych na inwestycje spadła o 739,5 mln zł, czyli o 57,8\% (tab. 5, 
ryc. 4). Wyraźnie zaznaczył się tutaj wpływ kryzysu gospodarczego ostatnich lat, przyczyniając się do zmniejszenia nakładów inwestycyjnych w 2008 roku o 266,3 mln zł w stosunku do roku poprzedniego, czyli o 24,2\%. Najwyższą wartością nakładów inwestycyjnych, charakteryzował się sektor budownictwa i przemysłu. W badanym okresie skupiał on powyżej $66 \%$ funduszy. Należy nadmienić, że po okresie spadku jego udziału w całości nakładów w 2008 roku pojawiła się tendencja wzrostowa: w 2011 roku aż 80,4\% nakładów inwestycyjnych było przeznaczonych na działalność przemysłową i budownictwo.

Tab. 5. Nakłady inwestycyjne w podziale na sektory gospodarcze w latach 2002-2011

\begin{tabular}{|c|c|c|c|c|}
\hline \multirow{2}{*}{ Lata } & \multirow{2}{*}{$\begin{array}{c}\text { Nakłady ogółem } \\
\text { w mln zł }\end{array}$} & $\begin{array}{c}|c| \\
\text { rolnictwo, } \\
\text { łowiectwo, } \\
\text { leśnictwo i rybactwo }\end{array}$ & $\begin{array}{c}\text { Struktura nakładów } \\
\text { i budownictwo }\end{array}$ & usługi \\
\hline 2002 & 1279,1 & 0,0 & 83,4 & 16,6 \\
\hline 2003 & 781,7 & 0,1 & 79,8 & 20,1 \\
\hline 2004 & 676,6 & 0,1 & 66,8 & 33,1 \\
\hline 2005 & 539,6 & 0,2 & 68,2 & 31,6 \\
\hline 2006 & 900,1 & 0,1 & 74,8 & 25,1 \\
\hline 2007 & 1102,8 & 0,1 & 77,2 & 22,7 \\
\hline 2008 & 836,5 & 0,2 & 71,7 & 28,1 \\
\hline 2009 & 1144,1 & 0,1 & 75,6 & 24,3 \\
\hline 2010 & 1031,3 & 0,1 & 76,0 & 23,9 \\
\hline 2011 & 960,0 & 0,0 & 80,4 & 19,6 \\
\hline
\end{tabular}

Źródło: opracowanie własne na podstawie danych GUS

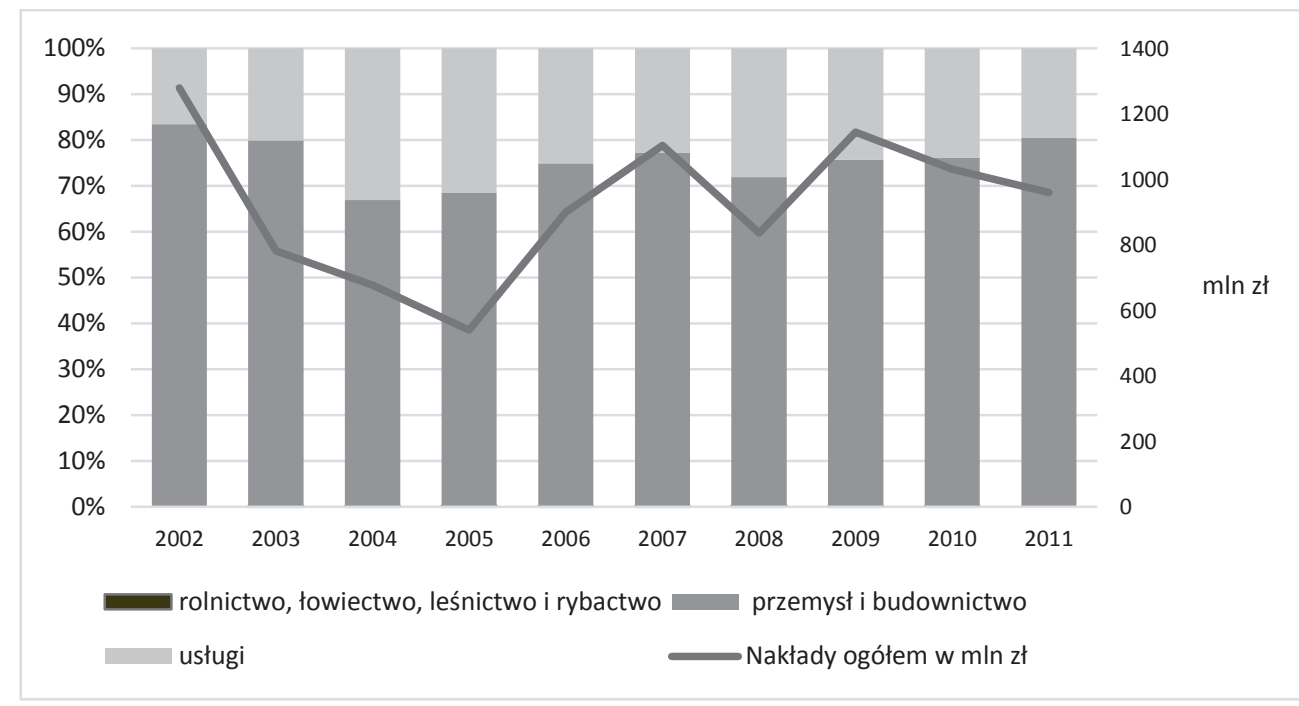

Ryc. 4. Wartość i struktura nakładów inwestycyjnych w podziale na sektory gospodarki w latach 2002-2011

Źródło: opracowanie własne na podstawie danych GUS 


\section{Podsumowanie}

Struktura bielskiego przemysłu w przeciągu ostatnich 20 lat uległa znacznemu przekształceniu. Zmiana ta w głównej mierze związana była z załamaniem się wiodącej dotychczas w mieście branży włókienniczej. W wyniku procesów transformacji ustrojowo-gospodarczej wiele zakładów zostało zlikwidowanych, część poddano prywatyzacji, znacznie ograniczono produkcję i zatrudnienie w sektorze przemysłowym. Dominujący w Bielsku-Białej od przeszło dwóch wieków przemysł lekki ustąpił miejsca przemysłowi elektromaszynowemu, a zwłaszcza przemysłowi motoryzacyjnemu.

Pomimo zachodzących zmian przemysł w dalszym ciągu pełni ważną rolę w aktywizacji zasobów pracy oraz skupia znaczną część podmiotów gospodarczych. Aby przeciwdziałać negatywnym skutkom transformacji i zdynamizować produkcję przemysłową, w Bielsku-Białej realizowane są liczne inwestycje, takie jak Park Przemysłowo-Technologiczny, Inkubator Przedsiębiorczości oraz włączenie kilku terenów miasta w skład KSSE. Działania te przyczyniają się zwłaszcza w ostatnich kilku latach do wzrostu liczby pracujących w przemyśle oraz zwiększenia nakładów inwestycyjnych na branżę przemysłowo-budowlaną. Ponadto, pod wpływem coraz bardziej nasilających się procesów globalizacji i integracji europejskiej, w Bielsku-Białej inwestuje wiele firm zagranicznych, przyczyniając się do rozwoju nowych zaawansowanych technologii, najczęściej w branży motoryzacyjnej, a także do aktywnej współpracy z ośrodkami naukowymi i naukowo-badawczymi.

Chociaż w związku ze światowym kryzysem gospodarczym w latach 2008-2009 zanotowano spadek zatrudnienia w branży przemysłowej, mniejszą aktywność w zakresie zakładania nowych przedsiębiorstw oraz ograniczenie nakładów na nowe inwestycje, to można tutaj mówić jedynie o krótkotrwałym spowolnieniu gospodarczym. Przeprowadzona analiza pozwala przypuszczać, iż w następnych latach będzie się w Bielsku-Białej umacniała rola przemysłu i będzie on odgrywał istotną rolę w rozwoju gospodarczym miasta.

\section{Literatura \\ References}

Bal-Woźniak, T., (2009). Infrastruktura systemu innowacyjnego jako czynnik transformacji struktur przemysłowych. Prace Komisji Geografii Przemystu Polskiego Towarzystwa Geograficznego, $12,45-57$.

Batorowicz, Z., Suliborski A. (1988). Geografia ekonomiczna Polski: makroregiony gospodarczo-planistyczne. Warszawa: Wydawnictwo Szkolne i Pedagogiczne.

Czapliński, P. (2006). Wpływ procesów transformacji na lokalne struktury przemysłu na przykładzie byłego województwa słupskiego. Prace Komisji Geografii Przemystu Polskiego Towarzystwa Geograficznego, 9, 52-61.

Gierańczyk, W., Stańczyk A. (2001). Okręgi przemysłowe w Polsce u progu XXI wieku, Prace Komisji Geografii Przemystu Polskiego Towarzystwa Geograficznego, 3, 61-69.

Inwestorzy KSSE (2013). Pozyskano z http://ksse.com.pl/inwestorzy.

Kaczmarek. R. (red.). (2010). Monografia miasta, t. 4: Bielsko-Biała w latach 1918-2009, Bielsko-Biała: Wydział Kultury i Sztuki Urzędu Miejskiego. 
Katowicka Specjalna Strefa Ekonomiczna (2013). Pozyskano z http://www.um.bielsko.pl/strona-368katowicka_specjalna_strefa_ekonomiczna.html.

Krepol - o firmie (2013). Pozyskano z http://www.krepolbw.pl/index.php?id=1\&lang=pl\&p=0.

Lenko - historia firmy (2013). Pozyskano z http://www.lenko.com.pl/index.php?str=3\&idm=1\&id $\mathrm{m}=11 \& \mathrm{ids}=11$,http://www.krepolbw.pl/index.php?id=1\&lang=pl\&p=0.

Park Przemysłowo-Technologiczny (2013). Pozyskano z http://www.um.bielsko.pl/strona-369-park_ przemyslowo_technologiczny.html.

Polak, J. (2000). Przewodnik po Bielsku-Białej, Bielsko-Biała: Towarzystwo Miłośników Ziemi Bielsko-Bialskiej.

Rachwał, T. (2010). Struktura przestrzenna i działowa przemysłu Polski na tle Unii Europejskiej w dwudziestolecie rozpoczęcia procesów transformacji systemowej. Prace Komisji Geografii Przemystu Polskiego Towarzystwa Geograficznego, 16, 105-124.

Rachwał, T. (2011). Wpływ kryzysu na zmiany produkcji przemysłowej w Polsce. Prace Komisji Geografii Przemystu Polskiego Towarzystwa Geograficznego, 17, 99-113.

Rozwój przemystu i przemiany struktury przestrzenno-gatęziowej województwa bielskiego w latach 1975 do 1985 (1986). Bielsko-Biała: Wojewódzki Urząd Statystyczny w Bielsku-Białej.

Śleszyński, P. (2007). Gospodarcze funkcje kontrolne w przestrzeni Polski. Prace Geograficzne Instytutu Geografii i Przestrzennego Zagospodarowania Polskiej Akademii Nauk, 213, 126-142.

Zioło, Z. (2011). Wpływ światowego kryzysu na tempo wzrostu gospodarki i światowych korporacji. Prace Komisji Geografii Przemystu Polskiego Towarzystwa Geograficznego, 17, 9-32.

Alina Haczek mgr inż., doktorantka w Instytucie Geografii Uniwersytetu Pedagogicznego im. KEN w Krakowie. Zainteresowania badawcze: transformacja funkcji miejskich aglomeracji bielskiej, bielski ośrodek akademicki, transformacja bielskiego ośrodka przemysłowego.

Alina Haczek, Ph.D. student at the Institute of Geography of the Pedagogical University in Krakow. Research interests: the transformation of urban functions in agglomeration of Bielsko-Biała, BielskoBiała academic Center, the transformation of Bielsko-Biała industrial center.

\section{Adres/adress:}

Uniwersytet Pedagogiczny w Krakowie

Instytut Geografii

ul. Podchorążych 2, 30-084 Kraków, Polska

e-mail: alina_haczek@wp.pl 